\title{
Os mapas da população no Estado do Grão-Pará: consolidação de uma população colonial na segunda metade do século XVIII
}

\author{
André Augusto da Fonseca*
}

\begin{abstract}
A partir de meados do século XVIII, no contexto das chamadas Reformas Pombalinas, as "Leis de Liberdade dos Índios” incorporaram uma vasta região no norte da América portuguesa à administração civil, transformando mais de 60 aldeamentos missionários em vilas e lugares portugueses de população majoritariamente indígena. Esta pesquisa propõe-se a investigar a evolução demográfica dos índios aldeados e da população livre não aldeada sob esse novo regime. Para uma parte da historiografia, a população das vilas e lugares indígenas, sob o Diretório (1757-1798), era mantida artificialmente pelo constante aporte de novos contingentes de povos nativos, por meio dos descimentos. No entanto, a análise dos mapas de população elaborados a partir de 1773 mostra um crescimento lento, mas consistente de todos os grupos da população das capitanias do Estado do Grão-Pará, mesmo sofrendo os danos das frequentes epidemias e do trabalho compulsório ao qual estava sujeita a maior parte da população indígena.

Palavras-chave: Amazônia - história colonial. Políticas indigenistas. Povos indígenas. Políticas indígenas.
\end{abstract}

\footnotetext{
*Universidade Estadual de Roraima (UERR), Boa Vista-RR, Brasil (andreaugfonseca@gmail.com).
} 


\section{Introdução}

Este trabalho propõe-se a contextualizar um conjunto de fontes de natureza estatística das capitanias do Pará e Rio Negro, discutindo seu desenvolvimento e inserção nas práticas administrativas do império português, bem como utilizar esses documentos para avaliar o impacto demográfico das chamadas reformas pombalinas. Trata-se dos mapas de população de 1762 a 1797 disponíveis no Arquivo Histórico Ultramarino (AHU) e na Biblioteca do Porto (Portugal).

Entre 1751 e 1759, uma série de reformas tomou corpo no norte da América portuguesa. Leis extinguindo o poder temporal dos missionários sobre a população indígena, proibindo toda forma de cativeiro dos povos nativos da América, estimulando e prestigiando o casamento entre portugueses e ameríndios e criando uma companhia privilegiada de comércio para o Estado do Grão-Pará e Maranhão ${ }^{1}$ procuravam transformar a realidade social, cultural, política e econômica da região. 0 poderoso ministro de D. José I, Sebastião José de Carvalho e Mello, colocara como governador do Estado seu irmão, Francisco Xavier de Mendonça Furtado, para reorganizar as finanças, as relações de trabalho e a defesa nessa parte do império que se tornara tão estratégica, depois da celebração do Tratado de Madri em 1750. A preocupação com o definhamento da população daquele domínio e a consciência da necessidade de mudanças já vinham do reinado anterior, de D. João V, e teriam continuidade nas décadas seguintes e mesmo no reinado subsequente de D. Maria I.

Parte da historiografia sobre o período avaliou que tais reformas, ao invés de recuperar a demografia e a economia do Estado, acabaram por provocar o oposto. Em um importante trabalho (que usou, de forma pioneira, alguns dos mapas de população produzidos no século XVIII), Maria Regina Celestino de Almeida (1990) afirmou que essas reformas portavam profundas e insanáveis contradições entre os interesses dos indígenas e dos portugueses.

0 resultado disso foi a criação de povoações artificiais e incapazes de se manterem por si mesmas. Eram fundadas e constantemente reabastecidas com migrações internas de populações indígenas deslocadas através dos descimentos, num processo de contínuo esvaziamento das aldeias de origem (ALMEIDA, 1990, p. 12).

Nessa mesma linha de interpretação, John Hemming (2009 [1978], p. 97) afirmava que os descimentos eram usados no período do Diretório para trazer "vários milhares de índios" para substituir as perdas das povoações, que mesmo assim diminuíam assustadoramente. Hemming, no entanto, valeu-se de algumas fontes qualitativas, mas não das contagens da população realizadas na época. Ronald Raminelli (1998), analogamente, a partir de fontes qualitativas e um número limitado de mapas de população parciais de distritos atípicos de uma capitania (fronteiras do rio Branco e alto rio Negro, em 1785),

\footnotetext{
${ }^{1}$ De 1621 a 1751, essa unidade administrativa era o Estado do Maranhão e Grão-Pará, com capital em São Luís. De 1751 a 1774, a capital transferiu-se para Belém e o Estado passou a chamar-se Grão-Pará e Maranhão, sendo formado pelas capitanias do Pará e as capitanias subordinadas do Rio Negro, Maranhão e Piauí. De 1774 até sua extinção, o Maranhão e o Piauí foram desmembrados do Estado, que passou a ser formado apenas pelas capitanias do Pará e do Rio Negro. Este trabalho concentra-se na população livre (indígena ou não) destas duas últimas capitanias.
} 
concluiu que "os povoados incentivados pelo Diretório Pombalino eram responsáveis por uma verdadeira catástrofe demográfica”, sendo as povoações da Amazônia colonial, de forma geral, “incapazes de reproduzir a vida econômica e social necessárias à colonização" (RAMINELLI, 1998, p. 1374).

Tais afirmações merecem ser reavaliadas à luz de um conjunto mais amplo de documentos estatísticos. Este trabalho discute algumas características das transformações demográficas pós-contato até o século XVIII e o desenvolvimento das técnicas de contagem de população no império português. Em seguida, utilizam-se os dados dos mapas de população para discutir a suposta insustentabilidade das povoações da Amazônia no período do Diretório. Sobretudo, os mapas produzidos entre 1773 e 1779 registraram, em cada uma das freguesias e povoações dessas capitanias, a população de homens e mulheres, a distribuição por idade, pessoas livres e escravos, informações de natalidade, mortalidade e migração. Se não há razões para duvidar de uma catástrofe demográfica no primeiro século e meio de conquista, provavelmente essa expressão não descreve a realidade da segunda metade do século XVIII.

\section{A população da Amazônia pós-contato}

As reformas pombalinas tiveram início possivelmente no ponto mais baixo da catástrofe demográfica indígena do período colonial na Amazônia. É bem conhecido o que se passou com os povos nativos da América como um todo, após a conquista. Para 1492, Denevan (2003) estimou o total da população do continente americano em 53,9 milhões de pessoas, ou, com uma margem de erro de $20 \%$ para mais ou para menos, entre 43 e 65 milhões (DENEVAN, 2003, p. 178; PORRO, 1995, p. 23). A redução da população pode ter sido, em grande parte do continente, da ordem de $90 \%$ a $97 \%$ no primeiro século de colonização (SANCHEZ-ALBORNOZ, 1990, p. 17; PORRO, 1995, p. 23). ${ }^{2}$

Somente para a região amazônica como um todo, Denevan (2003, p. 187) calcula que a população nativa em 1492 era de 5 a 6 milhões de pessoas ( 3 a 4 milhões para a bacia amazônica). Sobretudo a partir do primeiro quartel do século XVII, quando os luso-brasileiros se estabeleceram em São Luís e Belém, o impacto combinado dos patógenos trazidos pelos europeus, pelos descimentos, resgates, "guerras justas" e variadas formas de cativeiro legal ou ilegal de povos nativos reduziu drasticamente esse número. ${ }^{3}$

Por outro lado, se a heterogênea população nativa ameríndia passou pela recomposição étnica e pelo desaparecimento de diversos grupos, outras heterogeneidades viriam

\footnotetext{
2 Embora amplamente aceita, essa ordem de redução da população é tratada com cautela por Massimo Livi-Bacci (2016, p. 420).

${ }^{3}$ Como adverte Massimo Livi-Bacci (2016, p. 420-421), é impossível estabelecer um único modelo de despovoamento ou "depopulação" para todo o continente, dada a pluralidade tanto de estruturas sociais, políticas e econômicas ameríndias quanto de estratégias dos conquistadores europeus. Determinados fatores podem ter predominado em uma área, mas não em outra, assim como a redução demográfica foi diferente em cada região.
} 
a compor a população da região, voluntária ou involuntariamente, fossem os africanos ${ }^{4}$ de diversas origens trazidos pelos colonizadores, fossem os casais de açorianos, ${ }^{5}$ os soldados da Madeira, os degredados (CHAMBOULEYRON, 2010) ou os mazaganistas (VIDAL, 2008), assinalando os vínculos do nascente Estado do Maranhão com o império. No último quartel do século XVIII, como veremos, a ordem de grandeza da população total de súditos portugueses (índios, brancos, negros e mestiços) no rio Amazonas e cursos inferiores dos seus afluentes ainda seria inferior a 100 mil pessoas.

No século XVI, no Estado do Brasil, epidemias dizimaram as populações que sobreviveram às guerras do primeiro século. Em ambos os Estados da América portuguesa, nos séculos XVII e XVIII, a varíola e o sarampo causaram um impacto duradouro nas populações ameríndias independentes e aldeadas. Como explica Crosby (2011, p. 207):

Os indígenas das Américas e da Austrália permaneceram quase absolutamente isolados dos germes do Velho Mundo até as últimas centenas de anos [...]. Os ameríndios certamente conheciam o purupuru, a bouba, a sífilis venérea, a hepatite, a encefalite, a pólio, algumas variedades de tuberculose [...] e parasitos intestinais; mas parecem jamais ter tido alguma experiência com enfermidades do Velho Mundo como varíola, sarampo, difteria, tracoma, coqueluche, catapora, peste bubônica, malária, febre tifoide, cólera, febre amarela, dengue, escarlatina, disenteria amébica, gripe e uma série de manifestações helmínticas.

A resistência da população ameríndia era muito menor do que a dos europeus, pois os indígenas não tinham anticorpos para essas enfermidades; dessa forma, enquanto na Europa a varíola atingia principalmente crianças, entre os ameríndios atingia todas as faixas etárias. Mesmo na Europa, “as perdas demográficas têm consequências de longa duração, que se desfazem gradualmente só muito tempo depois de as gerações afetadas pela crise terem saído de cena" (LIVI-BACCI, 1984, p. 101). Epidemias de tifo e de peste, na Europa, causavam crises de mortalidade de tipo “a” (mortalidade jovem-adulta), enquanto as de varíola causavam uma crise de mortalidade de tipo "b” (mortalidade infanto-juvenil) (LIVI-BACCI, 1984, p. 105). Porém, "quando uma população é atacada pela primeira vez, todas as idades são atingidas” (BIRABEN, 1984, p. 128). 0 que tivemos na Amazônia no século XVII e na primeira metade do século XVIII foi, portanto, o pior dos mundos: uma combinação dos tipos "a" e "b".

No século XVIII a varíola espalhou-se até os confins ocidentais da Amazônia, como se vê na descrição de vários índios capturados no Japurá, Içá e Alto Rio Negro na década de 1740, registrados em Belém com sinais de bexigas. ${ }^{6}$ Na década de 1780, o militar Teodósio Constantino de Chermont escreveu um resumo das grandes epidemias que assolaram 0 Estado ao longo daquele século. Em 1724, dizia essa Memória, só na cidade do Pará e suas

\footnotetext{
${ }^{4}$ A minuciosa pesquisa de José Maia Bezerra Neto (2014) concluiu que 2.157 africanos escravizados teriam ingressado no Grão-Pará de 1680 a 1755 e 35.597 de 1756 a 1800.

${ }^{5}$ Somente entre 1647 e 1677, 1.114 povoadores açorianos foram introduzidos no Pará (CHAMBOULEYRON, 2010, p. 64).

6 Por exemplo, o “mocetão" de nação Baniwa "chamado Helias de idade ao parecer de dezoito anos com bastantes sinaes de bexigas" (termo de registro de primeiro de dezembro de 1747) (MEIRA, 1994, p. 163).
} 
vizinhanças teriam se contado 15 mil mortos, ceifados pelas bexigas (varíola). ${ }^{7}$ A população mal tinha tempo para recuperar-se antes de novas ondas de contágio. As expedições de resgate, intensificadas a partir de então, depois da guerra contra os Manau, levavam as doenças para os sertões e comunicavam as epidemias de volta à capital e arredores, junto com os cativos. Os mais atingidos eram os índios e, em menor escala, os mamelucos. Isso comprometia profundamente a produção e o transporte de alimentos, dependentes do trabalho indígena, o que amplificava as consequências das epidemias. Em 1740 a varíola voltou a grassar e, em 1749 , veio o "sarampo grande", de altíssima letalidade. ${ }^{8}$ Ainda de acordo com Chermont, de 1751 a 1759, duas epidemias de sarampo e varíola causaram estrago entre uma população indígena ainda não recuperada da devastação recente. Todas as atividades econômicas, assim como o serviço real, eram atingidas, embora a capital nunca mais tivesse sofrido estrago tão grande quanto na primeira metade do século. Em 1762, novamente entre 1763 e 1772, e ainda em 1776, houve diversos surtos de varíola que, embora "mais benignos" que os anteriores, teriam provocado baixas entre índios e escravos e "principalmente" na "mocidade da tropa, sendo vítimas dos seus estragos dous alferes e oitenta soldados". ${ }^{9}$ Posteriormente ao relato de Chermont, o príncipe regente D. João instaria o governo do Estado insistentemente a praticar a inoculação como forma de prevenção, entre 1798 e 1804, sem ser obedecido. As autoridades régias continuaram reportando epidemias até $1821 .^{10}$

Quando as comunidades atingidas são de dimensões reduzidas, como uma aldeia, a epidemia de varíola extingue-se rápida e espontaneamente, a não ser que as trocas com o mundo exterior sejam constantes, fazendo a moléstia circular de um grupo para outro sem se extinguir. Cidades com mais de 20 mil habitantes são um potencial repositório permanente de vírus, com surtos epidêmicos periódicos a cada quatro anos, aproximadamente (BIRABEN, 1984, p. 128). A primeira condição estava presente em alguns rios amazônicos setecentistas, com as frequentes expedições de resgate e de coleta de drogas, mas a segunda provavelmente não. Belém, o maior centro, não chegaria a ter essa dimensão no século XVIII. A periodicidade das epidemias citadas por Chermont pode se dever mais à sua condição de importante porto do Atlântico, receptor de africanos escravizados.

\footnotetext{
${ }^{7}$ Tenente-coronel Teodósio Constantino de Chermont, Memória dos mais terriveis contágios de bexigas e sarampo deste Estado desde o ano de 1720 por diante, posteriores às que manifestam os Anais Históricos do Maranhão, pelo Exmo. Sr. Bernardo Pereira de Berredo, nos anos de 1621 (§ 487) e de 1663 (§ 1109) (FERREIRA, 2007, p. 103-105).

${ }^{8}$ Essa epidemia de sarampo teria ceifado a vida de 3.348 pessoas na freguesia da Sé, em Belém, quase todas índias e mamelucas, chegando a um total de 16.494 mortes na capitania (VIEIRA JÚNIOR; MARTINS, 2015, p. 300). Para se ter uma ideia da catástrofe, a população indígena aldeada do Pará na segunda metade do século XVIII não ultrapassaria os 22 mil indivíduos. Quanto ao contágio da varíola, o então governador Francisco Pedro de Mendonça Gurjão afirmou ter tentado impor a quarentena às pessoas que iam de Belém a São Luís em 1747, mas foi baldado o esforço, pois a doença já havia chegado ao Maranhão (AHU_CU_013, Cx. 31, D. 2910).

${ }^{9} \mathrm{O}$ memorialista refere-se à tropa de linha, o que significa que a moléstia atingiu daquela vez os não-índios. Discutiremos adiante as marcas dessa crise demográfica nos mapas populacionais de 1777. 0 número de mortos nesse surto (superior a mil pessoas) levou as autoridades a discutirem a abertura de um novo cemitério para a capital (AHU_CU_013, Cx. 77, D. 6449). A mesma fonte refere-se explicitamente ao número significativo de brancos vitimados por esse episódio epidêmico. ${ }^{10}$ Pará, AHU_CU_013, Cx. 130, D. 9999; AHU_CU_013, Cx. 130, D. 9986; AHU_CU_013, Cx. 151, D. 11672.
} 
A partir de fontes de natureza estatística, como pretendemos demonstrar, é possível concluir que, depois de epidemias catastróficas anteriores a 1750, o sarampo e a varíola continuaram atingindo o Pará e o Rio Negro com uma certa periodicidade, porém com letalidade muito menor, uma vez que gradualmente se estabeleceu e consolidou uma população que não desconhecia esses patógenos. Parece ter havido uma estabilização e mesmo uma retomada gradual do crescimento da população ao longo da segunda metade do século. Embora o efeito dessas doenças fosse importante, a mortalidade geralmente não parece ter sido superior à natalidade, e a população colonial apresentou uma capacidade de crescimento.

\section{Classificar e contar os vassalos: primeiras tentativas}

Tentativas de contagem da população do conjunto das conquistas do Maranhão e Grão-Pará já aparecem no início do século XVIII, ${ }^{11}$ mas foi somente nas últimas décadas dessa centúria que as fontes de natureza estatística tornaram-se padronizadas e periódicas.

Em 1727 o rei João V pediu ao bispo do Pará que lhe enviasse uma lista de todos os moradores do bispado, incluindo os pequenos, e discriminando brancos, mamelucos e negros. ${ }^{12}$ Estes últimos, provavelmente, eram índios escravizados (“negros da terra”). Segundo o bispo, houve oposição dos moradores à pastoral e o próprio governador lhes insinuara que o cura perguntava pelos nomes dos escravos por querer tomá-los. Não é despropositado supor que esses temores eram motivados pela consciência, por parte dos moradores, da ilegitimidade generalizada do cativeiro indígena. Somente dois anos depois o bispo conseguiu enviar a lista solicitada pelo soberano, admitindo faltarem no cômputo os índios aldeados pelos mercedários e muitos escravos que os amos não quiseram revelar, por acharem que "não lhes convinha". Havia brancos e mamelucos pelos sertões fugidos da justiça, de quem os párocos não sabiam sequer os nomes, não tendo como incluí-los nas listas. "Enfim, fiz o que pude”, suspirava o bispo. ${ }^{13}$ Infelizmente, a lista remetida não foi conservada junto com a carta e não dispomos dos números que o bispo teria conseguido coligir, mas o episódio é um indício de como, na primeira metade do século, as contagens populacionais eram imprecisas e difíceis de executar (com a resistência dos moradores suplantando as forças das autoridades), além de não parecerem ter sido tão prioritárias aos agentes régios até então.

Em 1756, o bispo Miguel de Bulhões informava ao secretário de Estado de Marinha e Ultramar que a ordem real para que "cada hum dos párocos desta diocese” declarasse

\footnotetext{
${ }^{11}$ Ângelo Alves Carrara estima uma população de aproximadamente dez mil pessoas para as escassas povoações coloniais do final do século XVII, em todo o Estado do Maranhão e Grão-Pará. Entretanto, as fontes utilizadas para esse cálculo são meras estimativas coevas, e não contagens ou numeramentos (CARRARA, 2014).

12 1728, Setembro, 14, Belém do Pará. CARTA do Bispo do Pará, [D. fr. Bartolomeu do Pilar], para o rei [D. João V], sobre uma lista que elaborou com o número total de habitantes que compõem o seu bispado. AHU_CU_013, Cx. 11, D. 973.

13 1730, Setembro, 19, Belém do Pará. CARTA do Bispo do Pará, [D. fr. Bartolomeu do Pilar], para o rei [D. João V], enviando lista de todos os habitantes do seu bispado, à excepção das aldeias administradas pelos missionários de Nossa Senhora das Mercês e informando que o número de escravos é diminuto, porque os seus senhores não o quiseram revelar. AHU_CU_013, Cx. 12, D. 1138.
} 
todas as pessoas que havia de comunhão nas suas freguesias necessitaria de tanto tempo que não seria possível enviar as informações solicitadas na frota seguinte, mas prometia fazer tudo com "brevidade e prontidão". ${ }^{14} \mathrm{Um}$ ano depois, o bispo desculpava-se com o secretário pelo atraso, mas prometia remeter a relação na frota seguinte. ${ }^{15}$ Contudo, ele parece não ter voltado a tocar no assunto.

Até a década de 1760, não há muitos elementos para se calcular a população da região. ${ }^{16}$ Não parece ter fundamento a estimativa proposta por Lourenço Amazonas de 100 mil habitantes em 1750 para a metade ocidental do Estado do Grão-Pará (AMAZONAS, 1852, p. 241), mas mesmo Arthur Cezar Ferreira Reis (1989 [1931], p. 84) aceitou esses números sem objeções. 0 próprio Reis anotou, contudo, que a população total dessa mesma região, 17 anos depois, era de 5.289 pessoas (REIS, 1989 [1931], p. 124), o que mostra não ser plausível o número anterior. Boxer (1995, p. 290-291) considerava razoavelmente acurada a estimativa de João Lucio de Azevedo de uma população de 50 mil índios para as 63 missões de toda a Amazônia portuguesa antes da grande epidemia de varíola de 1749-1750. Ou seja, metade do que Lourenço Amazonas propunha apenas para a parte ocidental dessa região.

Em 1765, uma contagem da população da capitania do Pará foi coligida pelo vigário capitular Giraldo José de Abranches a partir dos róis de confessados. ${ }^{17} 0$ documento oferece a população de 61 freguesias e não discrimina os habitantes nem por sexo, nem por qualidade, mas apenas entre "menores" e "maiores", referindo-se à idade de comunhão (podiam comungar mulheres maiores de 12 anos de idade e homens maiores de 14 anos). Já as crianças com menos de sete anos, incapazes de se confessar, não eram incluídas nessas contagens (MADEIRA, 1999). ${ }^{18}$ Eventuais indígenas recém-descidos, ainda não batizados, não teriam sido contados, pela mesma razão. Corrigindo-se o único erro de soma do documento (100 pessoas a mais em Soure), temos um total de 33.654 habitantes para

\footnotetext{
14 1756, Novembro, 9, Pará. OFíCIO do [governador interino do Estado do Maranhão e Pará], Bispo do Pará, [D. fr. Miguel de Bulhões e Sousa], para o [ex-secretário de Estado da Marinha e Ultramar], Diogo de Mendonça Corte Real, sobre a ordem recebida para a realização um censo estatístico dos rios, lugares e povoações daquele Bispado. AHU_CU_013, Cx. 41, D. 3800. 15 1757, Novembro, 28, Pará. OFíCIO do [governador interino do Estado do Maranhão e Pará], Bispo do Pará, [D. fr. Miguel de Bulhões e Sousa], para o [secretário de Estado da Marinha e Ultramar], Tomé Joaquim da Costa Corte Real, sobre o atraso na entrega da relação dos lugares, povoações e freguesias pertencentes ao bispado do Pará. AHU_CU_013, Cx. 43, D. 3916.

${ }^{16}$ Ao contrário do que se verifica na América espanhola, dados demográficos da América portuguesa são muito escassos antes de meados do século XVIII (ALDEN, 1963, p. 175).

17 OFíclo do administrador do bispado do Pará, Giraldo José de Abranches, para o [secretário de estado da Marinha e Ultramar], Francisco Xavier de Mendonça Furtado. AHU_CU_013, Cx. 58, D. 5242. Dois elementos que sugerem alguma confiabilidade nesse tipo de contagem: os números não são arredondados e a possibilidade de o pároco conhecer cada paroquiano em comunidades tão pequenas é bem elevada (HOLLINGHSWORTH, 1977, p. 34).

${ }^{18}$ A diocese do Pará era sufragânea do arcebispado de Lisboa. As Constituições Primeiras do Arcebispado da Bahia, que seguiam as normas das arquidioceses de Lisboa e do Porto, nesse aspecto, determinavam nos Títulos XXXVI-XXXVII o controle da obrigação de todos os fiéis se confessarem e comungarem ao menos uma vez por ano, na quaresma, por meio de um "Rol pelas ruas, e casas, e fazendas de seus freguezes, o qual acabarão até a Dominga da Quinquagesima, sendo possivel, e nelle escreverão todos os seus freguezes por seus nomes, e sobrenomes, e os lugares, e ruas onde vivem." Esse rol nominal deveria diferenciar os maiores e menores de comunhão. Embora todos os maiores de sete anos estivessem obrigados a participar desse sacramento, os maiores ausentes sem justificativa estavam sujeitos a excomunhão e multa. Já a ausência dos rapazes menores de 14 anos e as moças menores de 12 sujeitava os pais a multa, mas não a excomunhão (CONSTITUIÇÕES Primeiras do Arcebispado da Bahia, feitas e ordenadas pelo Ilmo. e Rmo. Senhor D. Sebastião Monteiro da Vide, 1853 [1707]).
} 
a capitania do Pará. De acordo com Dauril Alden (1963, p. 191), nos “censos"19 ou mapas de população da América portuguesa em que pessoas de todas as idades eram contadas, as crianças de sete anos ou menos correspondiam em média a $11,75 \%$ da população total. Se essa informação puder ser usada para extrapolar os dados disponíveis na contagem de 1765, chegaríamos a um número ajustado de 38.134. Acrescentando uma estimativa de 1.200 habitantes para Oeiras, que não tinha sido incluída naquele cômputo, a provável população total da capitania naquele ano seria então de aproximadamente 39.334 habitantes.

Na mesma ocasião, o vigário capitular recebera os dados sobre a população da capitania do Rio Negro, mas recusou-se a incluí-los por considerá-los inverossímeis:

Da cappitania do Rio Negro veyo também a lista, mas com tão pouca certeza, e averiguação, que duvido a verdade della; por cuja razão me não atrevo a enviá-la a V. Exa., fazendo-se-me incrível, que tenha somente quatro mil, e tantas almas aquella Cappitania. ${ }^{20}$

Não obstante o ceticismo do compilador, “quatro mil e tantas almas" era uma cifra consistente com uma outra contagem realizada três anos antes pelo ouvidor daquela capitania, Lourenço Pereira da Costa, para a população total de índios aldeados das vilas e lugares da capitania do Rio Negro (PINHEIRO, 1983, p. 80-81). ${ }^{21}$ Somando a população de índios aldeados de cada uma das 18 povoações então existentes, o ouvidor chegou a um total de 4.799 pessoas. Sua relação dividia os índios aldeados entre "oficiais" (os principais, abalizados, sargentos-mores, etc.), os "índios de serviço" (certamente os homens entre 13 e 60 anos, excetuados os oficiais e suas famílias, nos termos do $\$ 12$ do Regimento das Missões ${ }^{22}$ e do $§ 64$ do Diretório ${ }^{23}$ ), “índias” (sem especificação de idade), "rapazes", "velhos” e “pagãos”.

\footnotetext{
$\overline{19}$ A palavra "censo" não era utilizada no século XVIII na acepção atual de recenseamento, contagem da população ou conjunto de dados estatísticos sobre um dado território, mas no sentido estrito de "renda de alguns bens de raiz, que se pagam ao direito senhorio" (BLUTEAU, 1716, p. 237, v.II). Ainda assim, alguns estudiosos utilizam o termo em seus trabalhos, com ou sem aspas, para se referir às contagens populacionais e estatísticas demográficas do Antigo Regime (ALDEN, 1963; MARCÍLIO, 1973; MARCÍLIO, 2000; BOTELHO, 2011; SAMPAIO, 2011; MATOS, 2013). Na consagrada periodização de Maria Marcílio, porém, as fontes de natureza demográfica dividem-se em uma fase pré-estatística (até primeira metade do século XVIII), uma fase proto-estatística (segunda metade do século XVIII até o primeiro recenseamento nacional de 1872) e uma era estatística, a partir de 1872 (MARCílIO, 2000). Este trabalho refere-se, portanto, à segunda fase.

${ }^{20}$ OFíCIO do administrador do bispado do Pará, Giraldo José de Abranches [...]. AHU_CU_013, Cx. 58, D. 5242.

21 Pinheiro (1983), ao transcrever o documento, atribuiu-lhe a data 1763, porém, no documento original (AHU_CU_020, Cx. 2, D. 113), vemos que se trata de informações de 1762, na verdade. Também foram corrigidas as somas que estavam erradas no original.

${ }^{22}$ O Regimento das Missões de 1686 (MATTOS, 2012) foi a legislação definida pela Coroa para disciplinar as relações entre os índios cristãos e os “moradores” no então Estado do Maranhão. Para autores como Carlos de Araújo Moreira Neto (1992) e Ylan de Mattos (2012), foi um diploma legal que representou uma solução de compromisso entre a resistência ameríndia, as forças dos lavradores ou moradores e as pressões das ordens missionárias - principalmente os jesuítas. Para Moreira Neto, embora contivesse diversas concessões por parte dos missionários, o Regimento das Missões permitiu uma fase de estabilização e crescimento das missões na Amazônia, que pode ser chamada de "período empresarial".

23 O “Diretório dos Índios" (FURTADO, 1758), proposto pelo então governador e capitão-general do Estado do Grão-Pará e Maranhão em 1757, e aprovado e transformado em lei pelo rei D. José em 1758, foi a regulamentação das Leis de Liberdade de 1755, estabelecendo a tutela de um diretor em cada uma das antigas povoações missionárias, agora transformadas em vilas e lugares administrados com participação das lideranças indígenas; também estipulava as condições de alocação dos trabalhadores compulsórios indígenas e as medidas de incentivo ao comércio e assimilação cultural dos ameríndios.
} 
O conjunto da população aldeada de toda a capitania do Rio Negro, portanto, perfazia um número pouco superior ao de uma das freguesias de Belém na década de 1760 . A população de pessoas livres exceto índios aldeados, somada à de escravos africanos, dificilmente ultrapassaria 1.300 pessoas em $1762,{ }^{24}$ o que sugere um teto provável de 6.100 pessoas para a população total da capitania do Rio Negro naquele ano. Este seria, sem dúvida, um número pequeno para uma capitania tão extensa, mas compatível com as contagens posteriores. A categoria "pagãos", que não surge em outros levantamentos encontrados, é muito significativa por dar uma dimensão da importância dos descimentos recentes, de contingentes ainda não batizados. 0 total de 412 pagãos ( $8,5 \%$ da população aldeada total) mostra como esse movimento era expressivo.

Não é possível calcular a razão de sexo ou a proporção de cada grupo etário, pois esses dados não estão desagregados no caso dos pagãos ou são imprecisos ("rapazes", "velhos").

Assim, os raros levantamentos estatísticos realizados antes da década de 1770 não seguiam uma diretriz quanto à organização ou a periodicidade. Isso começa a mudar em 1773.

\section{A padronização dos levantamentos estatísticos na década de 1770}

Foi somente no terceiro quartel do século XVIII que a Coroa gradualmente passou a exigir uma produção padronizada e regular de estatísticas populacionais (e, em seguida, econômicas) dos domínios de seu império, a exemplo da Espanha e da Inglaterra. 0 acirramento das rivalidades entre as diferentes potências coloniais demandava mais informação para finalidades fiscais e militares (ALDEN, 1963, p. 176).

Em 1761, a Coroa britânica solicitava que as colônias inglesas na América informassem periodicamente o número de brancos, negros e índios, bem como a razão para o crescimento ou diminuição das respectivas populações. A resposta a essa solicitação foi irregular, de forma análoga ao que aconteceria nos domínios ibéricos. Em 1776, tanto a Coroa portuguesa quanto a espanhola encaminharam uma demanda semelhante aos governadores dos seus domínios americanos. No caso português, de forma possivelmente inspirada em um modelo castelhano de 1768, as instruções de 1776 estendiam a todas as capitanias da América um modelo já aplicado desde 1765 em São Paulo, 1771 em Goiás ${ }^{25}$ e 1772 no Estado do Grão-Pará e Maranhão. Determinava-se que a população a ser contada anualmente deveria ser distribuída em: meninos de 0 a 7 anos; rapazes de 7 a 15 anos; homens de 15 a 60 anos; velhos acima de 60 anos; meninas de 0 a 7 anos; raparigas de 7 a 14 anos; mulheres de 14 a 40 anos; e adultas e velhas acima de 40 anos. ${ }^{26}$ Deveria ser

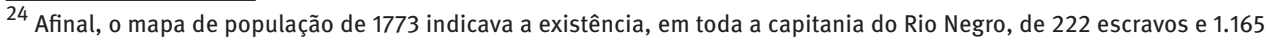
pessoas livres à exceção dos índios aldeados (AHU_CU_013, Cx. 72, D. 6100).

${ }^{25}$ Carta do secretário de Estado Martinho de Melo e Castro ao governador de Goiás José de Vasconcelos Soveral e Carvalho, 01/10/1771. In: Revista Trimensal do Instituto Histórico e Geográfico do Brasil, tomo XXVII, parte segunda, 1864, p. 257.

${ }^{26}$ Ordens régias em 1797 acrescentaram uma série de novas demandas de dados estatísticos e, principalmente, econômicos (MARCÍlIO, 2000, p. 38-39).
} 
informado ainda o número de nascimentos e mortes a cada ano (ALDEN, 1963, p. 177-179; MARCílIO, 2000, p. 35-38).

Nenhuma das instruções de 1771 a 1776, entretanto, solicitava a discriminação entre brancos, índios, negros e mestiços para a contagem da população das capitanias da América portuguesa (ALDEN, 1963, p. 179). Ainda assim, vários governadores decidiram incluir algum tipo de informação sobre a qualidade e a condição jurídica ${ }^{27}$ de seus governados (ALDEN, 1963, p. 184-185).

A instrução oficial mais antiga sobre a forma e os cuidados para a realização dos cômputos populacionais no Estado do Grão-Pará e Maranhão parece ser de 2 de outubro de 1772 e apresentava algumas pequenas diferenças nas divisões da população por idade e sexo, em relação à normativa de 1776: o grupo das mulheres adultas contemplava os intervalos entre 14 e 50 anos, 50 e 90 e acima de 90; o dos homens adultos, de 15 a 70 anos, 70 a 90 e acima de 90 . Em 25 de novembro de 1772, João Pereira Caldas (governador do Estado) comunicava a seu subordinado Tinoco Valente (governador do Rio Negro) essa instrução ${ }^{28}$ de Martinho de Melo e Castro (secretário de Estado de Marinha e Ultramar). Tal diretriz determinava que a contagem da população do Estado fosse realizada anualmente, tendo como referência as pessoas residindo em cada localidade no último dia do mês de junho de cada ano. Recomendava-se especial cuidado para que os párocos de cada freguesia, que "não costumão ordinariamente incluir nos seus róes de desobriga ${ }^{29}$ as crianças da idade de hum a sete anos, [...] não as omitão nos seus registos, para que os mapas se formem sempre com a maior exacção". O primeiro numeramento produzido com base nessas instruções é datado, de fato, de $1^{0}$ de julho de 1773 , mas todos os mapas posteriores $(1774$ a 1779,1785$)$ foram datados do dia 1 ํ de janeiro de cada ano. 0 modelo impresso ${ }^{30}$ enviado pelo secretário de Estado a Pereira Caldas orientava a divisão da população apenas entre "livres" e "cativos", mas o modelo ${ }^{31}$ que o governador do Estado envia para as capitanias subordinadas acrescentava a categoria "índios" (ou seja, índios aldeados) e transformava a categoria “livres” em "moradores adjuntos” (quer dizer, todos os livres à exceção dos índios aldeados).

Pereira Caldas, por sua vez, informava ao secretário de Estado de Marinha e Ultramar que remetera as instruções e os modelos aos governadores das capitanias do Estado e a

\footnotetext{
$\overline{27}$ A condição jurídica (livre, liberto ou escravo) não se confundia com a qualidade (branco, mulato, negro, preto, mameluco, cabra, cafuzo, etc.), embora ambas hierarquizassem socialmente os indivíduos. Além disso, a qualidade não era, prioritariamente, um marcador de "cor" (PAIVA, 2016, p. 71).

28 1773, Maio, 15, Pará. OFí́CIO do governador e capitão general do Estado do Pará e Rio Negro, João Pereira Caldas, para o [secretário de estado da Marinha e Ultramar], Martinho de Melo e Castro, AHU_CU_013, Cx. 70, D. 6002. Esse ofício incluía um modelo impresso das tabelas. Em 1776 e 1797, novas instruções para a contagem da população foram enviadas a governadores de todo o império (MATOS; SOUZA, 2015, p. 82).

${ }^{29}$ São os róis ou listas de confessados. Somente pessoas de comunhão podiam se confessar. Usa-se o termo "desobriga" referindo-se a desobrigar-se de confessar. "Desobrigar-se da quaresma. He satisfazer ao preceito da confissão, \& comunhão, que ordena a Igreja” (BLUTEAU, 1716, p. 159).

${ }^{30}$ AHU_CU_013, Cx. 72, D. 6100.

${ }^{31}$ AHU_CU_013, Cx. 70, D. 6002.
} 
todos os párocos das freguesias, para que as ordens fossem cumpridas com toda exatidão, apesar das enormes distâncias e das escassas luzes de alguns párocos:

[...] não obstante a clareza dos modelos dos Mappas, e da ordem com que lhos participei, eles não os entendem, antecipando-me a remessa, antes do fim de Junho, que thes determinei; mandando-me outros humas relações informes, e inteiramente confusas; e já houve algum, que me mandou perguntar, se os Regulares érão soldados Auxiliares, sendo aliás este dos que se tem em conta de mais esperto. ${ }^{32}$

Tinoco Valente, de Barcelos do Rio Negro, respondia ao governador do Estado que distribuiria as cópias dos modelos dos mapas "respectivos às Povoações de Índios", mas que "[...] O Segundo Modêllo para as Povoaçõens de brancos, como nesta Capitania se não encontre huma só, que assim se intitule, ou possa intitular, fica sustado athe V. Ex. ${ }^{\text {cia }}$ mandar o que for servido". ${ }^{33}$ Isto é, os "censos" das capitanias do Pará, do Maranhão e do Piauí distinguiam "povoações de brancos" e "povoações de índios", conforme a origem da formação de cada uma e conforme a qualidade majoritária de seus habitantes. Mas São José do Rio Negro era a única capitania da América portuguesa formada exclusivamente por povoações de índios - inclusive sua capital. É o que atestam todos os mapas de população do último quartel do século XVIII, utilizados neste trabalho.

A resposta de Tinoco Valente mostra que realmente existiam - ao menos para o Estado do Grão-Pará e Maranhão - um modelo de mapa para “as povoações de índios" e outro para as "povoações de brancos". 0 modelo para as povoações de índios simplesmente acrescenta uma seção de "índios aldeados, ou estabelecidos em povoações", com a discriminação por gênero e idade idêntica à das "pessoas livres" e "pessoas cativas". Também eram adicionadas colunas para nascimentos, mortes, acréscimos e decréscimos das populações indígenas.

Portanto, os "censos" realizados a partir de 1773 separavam os dados sobre a população conforme o estatuto jurídico, e não pela cor:

- livres com exceção dos índios aldeados (moradores), categoria na qual podiam entrar brancos europeus ou americanos, índios "adjuntos" ou não aldeados (que viviam sobre si), pretos forros, mestiços mamelucos, cafuzos e mulatos;

- índios aldeados (oficiais indígenas isentos do trabalho compulsório e índios também livres, mas sujeitos ao trabalho compulsório);

- escravos (que no contexto do Diretório eram de origem africana), compreendendo negros, cafuzos e mulatos cativos.

Somente alguns raros numeramentos, não regulares porém mais detalhados, como 0 Mapa das Famílias de 1778 (Pará e Rio Negro) ${ }^{34}$ ou o de 1788 (somente para Macapá),,35

\footnotetext{
32 AHU_CU_013, Cx. 70, D. 6002.

33 AHU_CU_013, Cx. 70, D. 6002.

34 AHU_CU_013, Cx. 94, D. 7509.

35 AHU_CU_013, Cx. 99, D. 7852.
} 
atribuíam a qualidade a cada morador livre não aldeado (branco, negro, mameluco, índio, cafuzo, mulato). Evidentemente, tal qualidade não dependia apenas das características fenotípicas, mas era determinada socialmente.

Porém, nos mapas gerais anuais de população do Pará, Rio Negro, Maranhão e Piauí, a desagregação dos dados estatísticos entre "livres não aldeados", "índios aldeados" e "escravos" não significava uma distinção de "qualidade" ou cor, mas de estatuto jurídico, com implicações óbvias na mensuração das possibilidades fiscais e militares das capitanias.

Do ponto de vista dos organizadores dos cômputos populacionais, duas motivações, uma pragmática e outra programática, podem ter orientado essa divisão dos levantamentos demográficos, especificando quem era índio aldeado e quem não era. Pragmaticamente, se a contagem de todos os vassalos livres era fundamental por razões militares e fiscais (oferecia informações consistentes sobre quem podia ser alistado nos corpos auxiliares e nas ordenanças, sobre o potencial de arrecadação do dízimo, etc.), a carga do trabalho compulsório pesava apenas sobre os índios aldeados que não eram oficiais. Por isso alguns mapas chegam a discriminar até mesmo quantos eram os oficiais índios e suas famílias em cada povoação do Estado, deixando claro quantos índios aldeados estavam empregados no serviço real ou no de particulares. Dentre os moradores, todos os homens em idade de pegar em armas podiam ser mobilizados para as forças auxiliares, mas nem todos os aldeados poderiam sê-lo, dadas as necessidades de remadores e outros trabalhadores para o transporte, comunicações, agricultura e manufatura do Estado.

Programaticamente, porque o Diretório mudara a política oficial sobre a presença de brancos nas povoações indígenas. Antes, o antigo Regimento das Missões vetava a presença de brancos e mamelucos, tida como uma ameaça de corrupção e violência contra os aldeamentos missionários. Sob o Diretório, moradores "de qualquer qualidade e condição", apresentando "exemplar procedimento", foram incentivados a cooperar, com seu exemplo e seus costumes, para a tarefa civilizatória com sua presença nas vilas e lugares indígenas (FURTADO, 1758, p. 34-37).

Os mapas de população e os relatórios de agentes régios (como os do ouvidor Ribeiro de Sampaio, do naturalista Alexandre Rodrigues Ferreira, dos bispos e vigários gerais) enviados a Lisboa permitiam à alta administração do império (no nível dos conselhos e das secretarias de Estado) monitorar o desenvolvimento das relações entre índios e brancos nesse laboratório de uma experiência civilizacional: quantos índios se dedicavam ao comércio, quantos trabalhavam para moradores brancos, quantos índios se evadiam a cada ano, quantos eram descidos, como se comportavam a natalidade e a mortalidade, qual proporção de não aldeados existia em cada uma das povoações de índios... Dessa forma, fazia sentido que tais contagens indicassem as populações de índios aldeados, escravos (africanos) e "livres à exceção de índios aldeados". Por essa razão, a classificação não é de "brancos", mas de "todos os livres exceto índios aldeados". Essa categoria incluía brancos, pretos forros, mulatos livres, mamelucos e índios não aldeados. 
Os pesquisadores que pioneiramente utilizaram os dados dos mapas populacionais certamente tiveram diante de si uma tarefa bastante desafiadora, antes da reorganização do Arquivo Histórico Ultramarino e disponibilização dos microfilmes na rede mundial de computadores. Os dados de que se dispunha (em um momento em que o acesso às fontes era muito mais difícil do que hoje) levaram Kelly-Normand $(1986, \text { p. } 95)^{36}$ a supor que a cada três anos se tentou fazer um "censo" geral da população do Estado do Grão-Pará. ${ }^{37}$ Na verdade, as instruções de Martinho de Melo e Castro em 1772 eram no sentido de que se realizassem as contagens anualmente.

A contagem da população, o controle da arrecadação e os relatórios sobre a produção passavam a ser feitos com regularidade e precisão inéditas, refletindo uma forma de administração bem diferente daquela que tínhamos visto nas primeiras tentativas de contagem da população. Trata-se da transformação de que fala Senellart (2006, p. 42-43): preocupadas com quantidades - "população ativa ou inativa, riquezas, mercadorias, equipamentos civis e militares" -, as monarquias agora procuravam desenvolver ao máximo os recursos materiais e humanos, pois as finalidades governamentais estavam sendo redefinidas em função das necessidades do Estado. Assim, "O antigo governo das almas e dos corpos é substituído [...] pelo governo das coisas".

A exatidão e a eficiência da coleta de informações certamente aumentaram nas últimas décadas do século XVIII, mas não são absolutas. Os agentes dessa contagem, fossem os párocos, os capitães ou cabos de ordenanças (mesmo na capitania de São Paulo, onde as contagens mereceram uma atenção particularmente zelosa sob o Morgado de Mateus), não tinham sempre os mesmos padrões de diligência e meticulosidade. "Como estes censos deveriam ser realizados anualmente, seus responsáveis limitavam-se, por vezes, em copiar as listas dos anos anteriores" (MARCílIO, 1973, p. 82). Para as capitanias do Rio Negro e do Pará, não se chegou a detectar esse tipo de fraude, mas as dificuldades e erros (intencionais ou não) eram quase inevitáveis em qualquer lugar. Até onde foi possível perceber, erros de soma eram muito raros e poucas vezes apareciam números redondos, o que é um indicador de cuidado nos levantamentos. Mas o despreparo dos encarregados provavelmente não era raro em uma capitania remota como a do Rio Negro. Ao organizar a contagem da população do lugar de Thomar, no rio Negro, o naturalista Alexandre Rodrigues Ferreira lamentava as dificuldades que teve em examinar os livros de ordenanças:

Maior trabalho reputei eu o da consternação, a que nos vimos reduzidos, eu, e o Reverendo Vigário, de aos próprios brancos, Índios, e Índias, andarmos perguntando pela gente ou das suas famílias, ou do seu conhecimento. Por isso eu não abono de exacto o Máppa da População, persuado-me contudo, que atendidas as circunstâncias da brevidade do

\footnotetext{
${ }^{36}$ Ela tinha pesquisado principalmente no Arquivo Nacional, no Rio de Janeiro, e salientou, corretamente, que o Arquivo do Conselho Ultramarino deveria ter muito mais material relativo aos "recenseamentos". Foi do Arquivo Histórico Ultramarino, afinal, que obtive a maior parte de minhas fontes, com a ferramenta do Projeto Resgate.

${ }^{37}$ A autora realizou um importante trabalho pioneiro sobre os "censos" na Amazônia colonial, embora tenha cometido alguns pequenos equívocos, como utilizar o termo "vila" (ligado a um estatuto bem definido de governo local) como sinônimo de "povoações" (KELLY-NORMAND, 1986, p. 99). Um trabalho anterior da mesma autora foi sua tese de doutorado baseada em fontes paroquiais da povoação de Gurupá (KELLY-NORMAND, 1984).
} 
tempo, confusão dos livros, novatice do Director, e do Vigario, e ausência dos Principaes, sahio tão exacto quanto se pode esperar sobre o exposto. ${ }^{38}$

\section{Análise dos mapas}

Com todas essas ressalvas, o que os mapas permitem inferir, a partir de 1773? Para Patrícia Sampaio (2011), pode ser observada uma relativa estabilidade da população aldeada que, em última análise, revela um Diretório “em pleno funcionamento”, com “o estabelecimento de populações de maneira mais ou menos duradoura". Mesmo com os já conhecidos casos de deserções e fugas, "tão importante quanto saber por que muitos se foram, é [...] tentar entender por que outros tantos ficaram" (SAMPAIO, 2011, p. 74). Não apenas ficaram, como conseguiram se estabelecer de forma consistente, conforme mostram os Gráficos 1 e 2.

GRÁFICO 1

População total

Capitanias do Pará e Rio Negro - 1773-1797

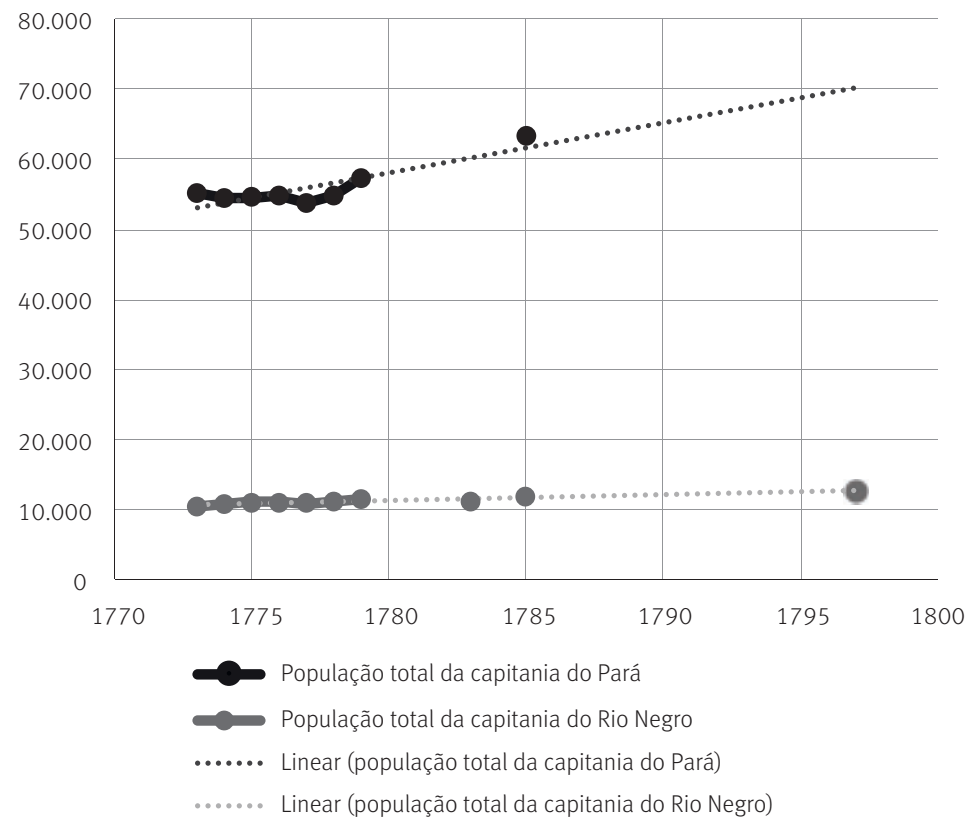

Fonte: Pinheiro (1983, p. 80-81); AHU CU 013, Cx. 58, D. 5242; AHU_CU_013, Cx. 72, D. 6100; AHU_CU_013, Cx. 74, D. 6252; AHU_CU_013, Cx. 74, D. 6256; AHU_CU_013, Cx. 76, D. 6368. AHU_CU_013; Cx. 85, D. 6940; AHU_CU_013, Cx. 94, D. 7509. Para os anos de 1783 e 1797: Almeida (1990). 
GRÁFICO 2

População de índios aldeados

Capitanias do Pará e Rio Negro -1762-1797

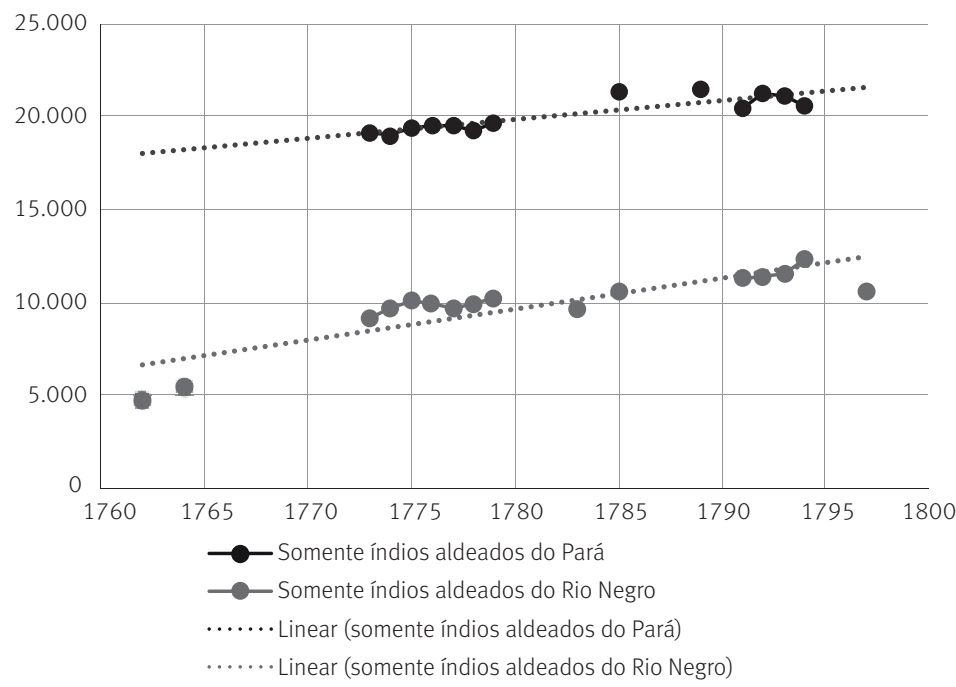

Fonte: AHU_CU_013, Cx. 99, D. 7872; AHU_CU_020, Cx. 2, D. 120; Mapas gerais da população dos índios aldeados em todas as povoações das capitanias do Estado do Grão-Pará e São José do Rio Negro, 1791 a 1794 - Biblioteca Municipal do Porto C-M \& A-Pasta 24 [65]. Para a capitania do Rio Negro, nos anos de 1773 e 1783: Almeida (1990).

Os mapas de população do período do Diretório refletem os sistemas hierárquicos em vigor: "dizer apenas índio não esclarecia muito sobre quem se falava, sem que se agregassem os distintivos moradores e aldeados” (SAMPAIO, 2011, p. 76). Uma distinção importante para as finalidades da contagem da população é que índios moradores, diferentemente dos aldeados, não estavam disponíveis para o trabalho compulsório. Os primeiros já podiam "viver sobre si”, desobrigados da tutela a que o aldeado estava submetido. Sem embargo de manterem uma identidade indígena (de se verem e serem vistos como índios), para efeitos administrativos, econômicos e militares, não precisavam ser distinguidos dos outros moradores pobres, brancos, mamelucos, cafuzos ou pretos.

De forma geral, todos os grupos livres apresentaram um crescimento que não destoa do resto da América portuguesa. Calculando-se a taxa média de crescimento anual da população total (livres, índios aldeados e escravos de todas as idades) a partir dos mapas de população da capitania do Pará entre 1773 e 1785, obtém-se a cifra de 1,11\%. Dauril Alden (1963, p. 194) admite uma taxa muito semelhante de crescimento anual (1,18\%) para o conjunto da América portuguesa, no último quartel do século XVIII. Para a capitania do Rio Negro, no mesmo período, a taxa é bastante similar (1,28\%). No que se refere apenas aos índios aldeados, a taxa média de crescimento anual no Pará de 1773 a 1794 é de apenas 0,33\% e, no Rio Negro, de 1,24\%.

Patrícia Sampaio (2011, p. 63) relaciona o aumento demográfico mais acelerado dos índios aldeados nessa última capitania, entre 1764 e 1774, a uma conjuntura de rápida expansão para oeste, com a fundação de várias novas povoações resultantes de descimentos. 
De fato, o Gráfico 2 mostra uma desaceleração do crescimento entre os aldeados da capitania do Rio Negro após 1780.

Mas, se o crescimento da população total é um pouco mais acelerado do que o efetivo de índios aldeados, é preciso levar em conta que tais categorias não eram estanques, pois existiam indivíduos que passavam da categoria "índios aldeados" para a de moradores, ou seja, saíam da condição de tutelados para a de vassalos com direitos realmente iguais aos dos demais vassalos. A absorção de índios como moradores pelo casamento e, principalmente, pelo concubinato certamente já ocorria em alguma medida antes das Leis das Liberdades (BOXER, 1967, p. 132), mas agora isso acontecia em outra escala, de forma institucionalizada, regulada e expandida para todo o interior do Estado. Alguns índios buscavam outras formas de passar para a categoria de moradores ou adjuntos das povoações, rejeitando a condição de tutelados.

TABELA 1

População total

Capitanias do Pará e do Rio Negro - 1765-1797

\begin{tabular}{lrr}
\hline Anos & Capitania do Pará & Capitania do Rio Negro \\
\hline 1765 & $(1) 39.334$ & $(2) 6.767$ \\
1766 a 1772 & n.d. & n.d. \\
1773 & 55.318 & 10.296 \\
1774 & 54.464 & 10.826 \\
1775 & 54.374 & 11.259 \\
1776 & 54.899 & 11.056 \\
1777 & 53.657 & 10.952 \\
1778 & 54.914 & 11.234 \\
1779 & 57.251 & 11.513 \\
1780 a 1782 & n.d. & n.d. \\
1783 & n.d. & 11.097 \\
1784 & n.d. & n.d. \\
1785 & 63.162 & 12.007 \\
1786 a 1796 & n.d. & n.d. \\
1797 & n.d. & 12.707 \\
\hline
\end{tabular}

Fonte: Pinheiro (1983, p. 80-81); AHU_CU_013, Cx. 58, D. 5242; AHU_CU_013, Cx. 72, D. 6100; AHU_CU_013, Cx. 74, D. 6252; AHU_CU_013, Cx. 74, D. 6256; AHU_CU_013, Cx. 76, D. 6368. AHU_CU_013; Cx. 85, D. 6940; AHU_CU_013, Cx. 94, D. 7509. Para os anos de 1783 e 1797: Almeida (1990).

(1) Total ajustado a partir do acréscimo do número estimado de menores de sete anos e da provável população de Oeiras.

(2) Total ajustado pela soma da população aldeada, contada em 1764, com uma estimativa de 1.300 habitantes brancos, índios

não aldeados, negros e mestiços.

A população aldeada da capitania do Rio Negro era aproximadamente a metade daquela do Pará, mas recebia maiores aportes de descimentos por ainda existirem mais povos independentes ali. A população aldeada do Pará permaneceu praticamente estável, enquanto a população total da capitania cresceu mais de $14 \%$ entre 1773 e 1785.0 número de "pessoas que se retiraram" (emigração, deserção das povoações) podia, em determinados anos, ultrapassar o número de mortes; assim como o número de "pessoas que se acresceram" podia ultrapassar o número de nascimentos. Mas essas pessoas que 
"se retiravam", evadiam ou se ausentavam das povoações podiam retornar algum tempo depois, assentar-se em outra freguesia ou mesmo passar da categoria de aldeado para a de livre não aldeado (morador).

TABELA 2

População de índios aldeados

Capitanias do Pará e do Rio Negro - 1762-1797

\begin{tabular}{|c|c|c|}
\hline Anos & Capitania do Pará & Capitania do Rio Negro \\
\hline 1762 & n.d. & 4.799 \\
\hline 1763 & n.d. & n.d. \\
\hline 1764 & n.d. & 5.467 \\
\hline 1765 a 1772 & n.d. & n.d. \\
\hline 1773 & 19.123 & 9.099 \\
\hline 1774 & 19.034 & 9.661 \\
\hline 1775 & 19.328 & 10.121 \\
\hline 1776 & 19.511 & 9.900 \\
\hline 1777 & 19.573 & 9.732 \\
\hline 1778 & 19.179 & 9.976 \\
\hline 1779 & 19.588 & 10.247 \\
\hline 1780 a 1782 & n.d. & n.d. \\
\hline 1783 & n.d. & 9.655 \\
\hline 1784 & n.d. & n.d. \\
\hline 1785 & 21.383 & 10.581 \\
\hline 1786 a 1788 & n.d. & n.d. \\
\hline 1789 & 21.513 & n.d. \\
\hline 1790 & n.d. & n.d. \\
\hline 1791 & 20.500 & 11.313 \\
\hline 1792 & 21.245 & 11.405 \\
\hline 1793 & 21.103 & 11.588 \\
\hline 1794 & 20.524 & 12.368 \\
\hline 1795 e 1796 & n.d. & n.d. \\
\hline 1797 & n.d. & 10.686 \\
\hline
\end{tabular}

Fonte: AHU_CU_013, Cx. 99, D. 7872; AHU_CU_020, Cx. 2, D. 120; Mapas gerais da população dos índios aldeados em todas as povoações das capitanias do Estado do Grão-Pará e São José do Rio Negro, 1791 a 1794 - Biblioteca Municipal do Porto C-M \& A-Pasta 24 [65]. Para a capitania do Rio Negro, nos anos de 1773 e 1783: Almeida (1990).

Os índices de mortalidade dos livres não aldeados parecem ser ligeiramente inferiores aos dos índios aldeados, exceto para 1777-1778 (Gráficos 3 e 4). Em 1776, como se sabe, houve uma séria epidemia de varíola em Belém. Se existe uma correlação entre esses fatos, a letalidade parece ter sido surpreendentemente maior no primeiro grupo do que no segundo, possivelmente por ter atingido mais a capital. ${ }^{39}$ Cada mapa da população era datado de primeiro de janeiro e apresentava os dados do ano anterior, como vimos. Portanto, o número de mortes que aparece no mapa de 1777 refere-se ao ano anterior. Em 1779, cessados os efeitos, as taxas voltam a patamares semelhantes aos de antes da epidemia.

\footnotetext{
39 1777, Setembro, 15: OFí́CIO do Bispo do Pará para o [secretário de estado dos Negócios do Reino], visconde de Vila Nova de Cerveira, sobre a necessidade de se construir um cemitério na vizinhança da cidade de Belém do Pará, em virtude do elevado número de pessoas falecidas devido a uma epidemia de bexigas. AHU_CU_013, Cx. 77, D. 6449.
} 
Esse padrão fortemente oscilante não destoa da "mortalidade do tipo Antigo Regime”. Nesse modelo, enquanto a natalidade mantinha-se relativamente constante, a mortalidade oscilava anualmente (Gráficos 3 e 4). Dependendo dos períodos de crise que surgiam, esse índice de mortalidade podia exceder ao de nascidos (IMHOF, 1984, p. 250). As taxas de natalidade dos índios aldeados assemelham-se às dos livres não aldeados (Gráficos 3 e 4 e Tabela 3), ao menos na conjuntura 1773-1779, para a qual pudemos obter dados contínuos.

\section{GRÁFICO 3}

Taxas de natalidade e mortalidade (1) dos índios aldeados Capitanias do Pará e do Rio Negro - 1774-1779

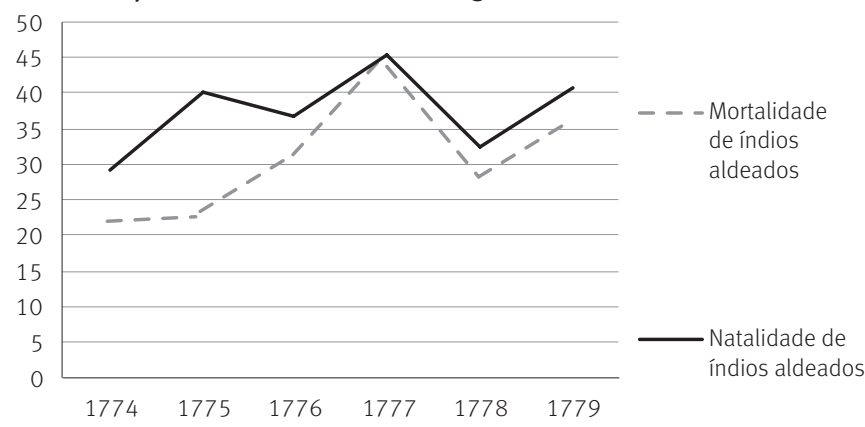

Fonte: Gráfico elaborado a partir dos números absolutos nos mapas de população de 1774 a 1779 (AHU_CU_013, Cx. 72, D. 6100; AHU_CU_013, Cx. 73, D. 6174; AHU_CU_013, Cx. 74, D. 6256; AHU_CU_013, Cx. 76, D. 6368; AHU_CU_013, Cx. 85, D. 6940). (1) Por mil índios aldeados.

GRÁFICO 4

Taxas de natalidade e mortalidade das pessoas livres exceto índios aldeados Capitanias do Pará e do Rio Negro - 1774-1779

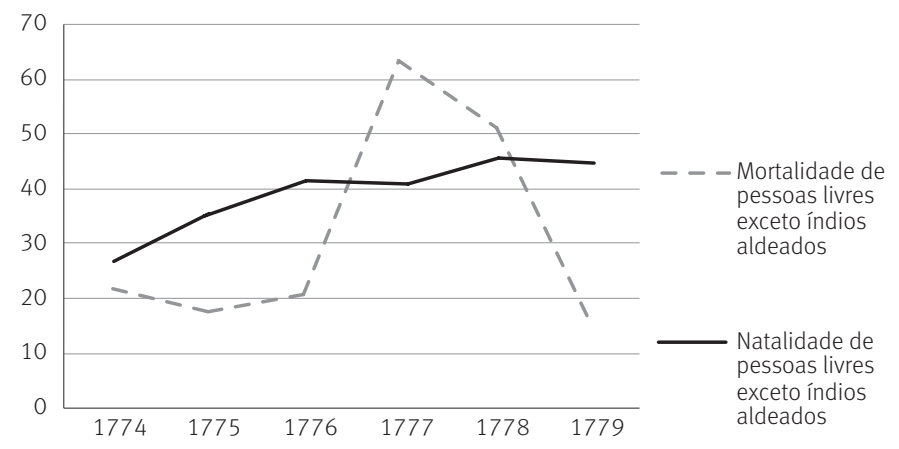

Fonte: Gráfico elaborado a partir dos números absolutos nos mapas de população de 1774 a 1779 (AHU_CU_013, Cx. 72, D. 6100; AHU_CU_013, Cx.73, D. 6174; AHU_CU_013, Cx. 74, D. 6256; AHU_CU_013, Cx. 76, D. 6368; AHU_CU_013, Cx.85, D. 6940). (1) Por mil pessoas livres.

Como base de comparação, em Minas Gerais, em 1815, a taxa de natalidade era de 36,6 por mil, para os brancos, e 41,7 por mil, para os mulatos livres, e a taxa de mortalidade correspondia a 27,4 e 34,3 por mil, respectivamente, para esses dois segmentos (MARCÍlIO, 1990, p. 59). Em seu estudo sobre uma região açucareira, Schwartz (1988, p. 63) oferece outros dados para comparação: 
A taxa bruta de mortalidade em Pernambuco em 1774 era de quase 33 por mil, e permaneceu em torno desse nível até o final do século XIX. No Maranhão, a taxa bruta de mortalidade dos indígenas em 1798 esteve próxima de 22 por mil, ao passo que para os escravos negros era pouco mais de 27 por mil. Portanto o percentual encontrado para o Engenho Santana parece elevado [43 por mil], embora não se aproxime da taxa de 70 por mil verificada para os escravos africanos na Jamaica e em Barbados no final do século XVII.

TABELA 3

Cálculo das taxas de mortalidade e natalidade Capitanias do Pará e Rio Negro - 1773-1779

\begin{tabular}{|c|c|c|c|c|c|c|c|}
\hline População & 1773 & 1774 & 1775 & 1776 & 1777 & 1778 & 1779 \\
\hline População total (Pará e Rio Negro) & 65.614 & 65.290 & 65.633 & 65.955 & 64.609 & 66.148 & 68.764 \\
\hline Escravos & 11.607 & 12.088 & 11.422 & 12.492 & 11.943 & 12.347 & 13.188 \\
\hline Índios aldeados & 28.222 & 28.695 & 29.443 & 29.411 & 29.305 & 29154 & 29.835 \\
\hline População livre exceto índios aldeados & 25.785 & 28.695 & 24.768 & 24.052 & 23.361 & 24.647 & 25.741 \\
\hline Mortes de livres exceto índios aldeados & n.d. & 538 & 436 & 499 & 1480 & 1261 & 389 \\
\hline Mortes de índios aldeados & n.d. & 631 & 688 & 926 & 1.324 & 825 & 1.077 \\
\hline $\begin{array}{l}\text { Nascimentos de livres exceto índios } \\
\text { aldeados }\end{array}$ & n.d. & 653 & 882 & 996 & 945 & 1.123 & 1.146 \\
\hline Nascimentos de índios aldeados & n.d. & 840 & 1.178 & 1.086 & 1.331 & 943 & 1.223 \\
\hline $\begin{array}{l}\text { Taxa de mortalidade de livres exceto } \\
\text { índios aldeados (por mil) }\end{array}$ & n.d. & 21,9 & 17,6 & 20,7 & 63,3 & 51,1 & 15,1 \\
\hline $\begin{array}{l}\text { Taxa de mortalidade de índios aldeados } \\
\text { (por mil) }\end{array}$ & n.d. & 21,9 & 23,3 & 31,4 & 45,1 & 28,3 & 36,1 \\
\hline $\begin{array}{l}\text { Taxa de natalidade de livres exceto índios } \\
\text { aldeados (por mil) }\end{array}$ & n.d. & 26,6 & 35,6 & 41,4 & 40,4 & 45,5 & 44,5 \\
\hline $\begin{array}{l}\text { Taxa de natalidade de índios aldeados } \\
\text { (por mil) }\end{array}$ & n.d. & 29,2 & 40,0 & 36,9 & 45,4 & 32,3 & 40,9 \\
\hline
\end{tabular}

Fonte: AHU_CU_013, Cx. 72, D. 6100; AHU_CU_013, Cx. 73, D. 6174; AHU_CU_013, Cx. 74, D. 6256; AHU_CU_013, Cx. 76, D. 6368; AHU_CU_013, CX. 85, D. 6940.

Nota: Os números absolutos foram compilados dos mapas de população do Arquivo Ultramarino (AHU - Projeto Resgate) já mencionados; as taxas de natalidade e mortalidade foram calculadas pelo autor, dividindo-se o número absoluto de mortes ou nascimentos de cada grupo pela respectiva população e multiplicando-se o resultado por mil. 0 mapa de 1773 não podia mostrar as variações populacionais do ano anterior porque foi o primeiro a ser feito de acordo com as instruções de 1772.

As taxas do Pará e do Rio Negro não parecem ser, portanto, excepcionais.

Incidentalmente, a Tabela 3 e o Gráfico 5 mostram que, até 1779, a população de escravos de origem africana equivalia a menos da metade da população indígena aldeada nas duas capitanias. A importância do trabalho indígena permaneceria central em todo 0 período colonial na região, mesmo com toda a política oficial de incentivo à importação de escravos africanos.

Os três grupos (índios aldeados, livres não aldeados e escravos) apresentam um crescimento lento, mas constante, no período. 0 Gráfico 5 demonstra isso, acrescentando os dados de $1785,{ }^{40}$ quando se observa pela primeira vez a população livre não aldeada ultrapassar os índios aldeados.

$\overline{{ }^{40} \text { AHU_CU_013, Cx. 94, D. } 7509 .}$ 


\section{GRÁFICO 5}

População, por grupos

Capitanias do Pará e Rio Negro - 1773-1785

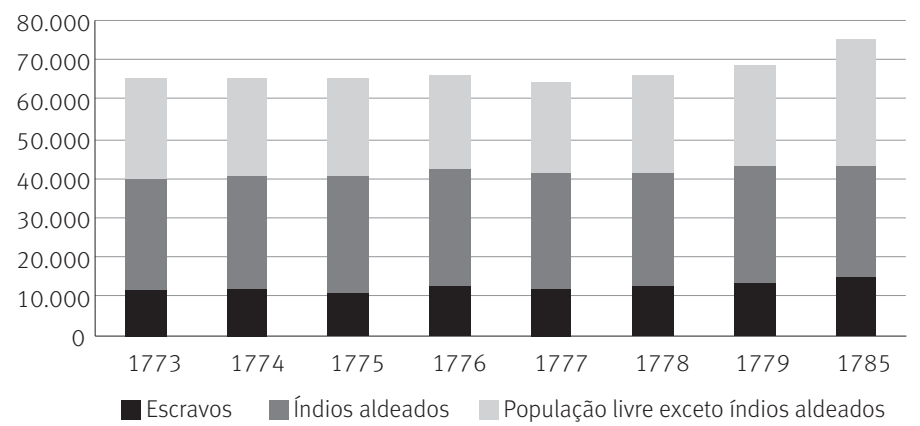

Fonte: AHU_CU_013, Cx. 72, D. 6100; AHU_CU_013, Cx. 73, D. 6174; AHU_CU_013, Cx. 74, D. 6256; AHU_CU_013, Cx. 76, D. 6368; AHU_CU_013, Cx. 85, D. 6940; AHU_CU_013; Cx. 94, D. 7509.

De forma geral, as áreas economicamente mais articuladas ao abastecimento interno e à exportação em cada capitania eram as que abrigavam as maiores parcelas dessa população. Dividindo-se as capitanias em regiões e calculando-se as respectivas porcentagens da população total nos mapas de 1765/1762, 1776 e 1785, obteve-se a distribuição geográfica dos habitantes ao longo de três décadas (Tabelas 4 e 5).

TABELA 4

Distribuição geográfica da população

Capitania do Pará - 1765-1785

\begin{tabular}{lccc} 
& \multicolumn{2}{c}{ Em porcentagem } \\
\hline Localidades & $\mathbf{1 7 6 5}$ & $\mathbf{1 7 7 6}$ & $\mathbf{1 7 8 5}$ \\
\hline Belém e região oriental do Pará & 47,5 & 46,6 & 52,1 \\
Baixo Amazonas & 15,4 & 18,1 & 17,8 \\
Cabo Norte & 14,9 & 9,0 & 4,5 \\
Marajó & 6,9 & 8,5 & 6,7 \\
Rio Tapajós & 6,1 & 7,0 & 6,3 \\
Rio Tocantins & 5,7 & 6,5 & 8,7 \\
Rio Xingu & 3,5 & 4,4 & 4,0 \\
\hline
\end{tabular}

Fonte: As povoações foram agrupadas em regiões pelo autor e os números absolutos foram obtidos nos respectivos mapas de população (AHU_CU_013, Cx. 58, D. 5242; AHU_CU_013, Cx. 74, D. 6256; Cx. 94, D. 7509).

TABELA 5

Distribuição geográfica da população Capitania do Rio Negro - 1762-1785

\begin{tabular}{lccc}
\hline Localidades & $\mathbf{1 7 6 2}$ & $\mathbf{1 7 7 6}$ & $\mathbf{1 7 8 5}$ \\
\hline Baixo Rio Negro & 51,7 & 39,2 & 38,9 \\
Solimões & 36,8 & 29,6 & 22,5 \\
Alto Rio Negro & 0,0 & 19,5 & 22,5 \\
Amazonas & 4,9 & 8,5 & 13,9 \\
Madeira & 6,6 & 3,2 & 2,1 \\
\hline
\end{tabular}

Fonte: As povoações foram agrupadas em regiões pelo autor e os números absolutos foram obtidos nos respectivos mapas de população (AHU_CU_020, Cx. 2, D. 113; AHU_CU_013, Cx. 74, D. 6256; Cx. 94, D. 7509). 
Na capitania do Pará, quase metade da população estava concentrada em Belém e região ocidental (o chamado "Continente do Pará"). ${ }^{41}$ Era justamente essa região, "a partir do sistema fluvial composto pelos rios Acará, Moju, Capim e Guamá” (CHAMBOULEYRON, 2010, p. 104), que desde fins do século XVII abarcava a maior parte das concessões de sesmarias e as atividades agrícolas comerciais.

O Baixo Amazonas ${ }^{42}$ reunia entre $17 \%$ e $18 \%$ da população. 0 Cabo Norte ${ }^{43}$ apresentou forte declínio em termos absolutos e proporcionais dos anos 1760 até a década de 1780; a porcentagem de Marajó, ilha ligada ao abastecimento da capital, permaneceu estável. Essas quatro áreas, que representavam $80 \%$ da população da capitania, concentravam igualmente a maior parte da população escrava (VIRGOLINO-HENRY; FIGUEIREDO, 1990, p. 53). Belém e as 14 vilas denominadas "vilas de brancos" da região oriental, aliás, possuíam 10.105 escravos ou $67 \%$ do total de escravos da capitania. O Rio Tocantins apresentou tendência de crescimento, enquanto os Rios Xingu e Tapajós mantiveram sua proporção (cerca de $4 \%$ e $6 \%$ da população da capitania, respectivamente).

Na capitania do Rio Negro, o Baixo Rio Negro (de Poiares à Barra do Rio Negro), com a capital e vilas importantes como Moura, apresentou redução relativa, entre 1762 e 1785 (de $51,7 \%$ para $38,9 \%$ da população), mas manteve sua preponderância. As povoações do Solimões, ${ }^{44}$ área considerada mais fértil, piscosa e rica em drogas do sertão do que o rio Negro, tiveram paradoxalmente um declínio significativo, de $36,8 \%$ para $22,5 \%$ no mesmo período, chegando a se igualar à região do Alto Rio Negro, ${ }^{45}$ uma fronteira remota com reduzida produção para o mercado interno ou externo e com uma população quase que exclusivamente indígena, recém-descida (depois de 1762).

As duas vilas do rio Amazonas, próximas ao Pará (Silves e Serpa), mostraram uma assinalada tendência de crescimento no período estudado, de menos de $5 \%$ para $13,9 \%$ da população da capitania, possivelmente pela conexão com a produção agrícola mercantil; 46 aliás, logo depois, em 1786, Serpa seria um dos estabelecimentos escolhidos para abrigar os Mura recém-pacificados, o que aumentou ainda mais sua população. Serpa e Silves eram as duas vilas com maior número de escravos em 1785, depois da capital (87 escravos ou

\footnotetext{
41 Incluindo áreas de colonização antiga como Vigia e Bragança, a expressão “Continente do Pará” era utilizada pelo padre José Monteiro de Noronha, vigário geral do Rio Negro (NORONHA, 1862 [1768], p. 2).

42 Desde Faro até Melgaço e Portel, incluindo Gurupá, Oeiras, Óbidos, Monte Alegre, etc.

43 Correspondendo ao atual Amapá, compreendendo Macapá, Santana, Vila Vistosa e Mazagão.

44 Compreendia povoações como Ega, Olivença, Fonte Boa, Tabatinga, entre outras.

45 Ou seja, a montante de Poiares, incluindo desde Santa Isabel até Marabitenas, São Gabriel, Caldas, Loreto etc., estabelecimentos posicionados em frente aos espanhóis.

${ }^{46}$ Silves, com 1.800 habitantes no final do século XVIII e início do XIX, destacava-se pela produção de tabaco, cacau, café, algodão e salga de peixe; Serpa, com 800 habitantes, produzia tabaco, manteiga e salga de peixe (SAMPAIO, 1825 [1775], p. 3-14; BARATA, 1846 [1797], p. 10; SOUSA, 1848, p. 422-423).
} 
$27,4 \%$ do total da capitania)..$^{47} 0$ rio Madeira (praticamente com uma única vila, Borba) não atingiu as expectativas iniciais que remontavam à década de 1750 , quando Mendonça Furtado o vislumbrava como importante ligação com Mato Grosso.

\section{Conclusão}

Percebe-se, assim, que poucas áreas de cada capitania apresentaram declínio demográfico significativo em termos relativos. Apenas as regiões do Cabo Norte e do Solimões, além da vila de Borba (rio Madeira), apresentaram diminuição absoluta entre 1765 e 1785. Os índices de natalidade, mortalidade e crescimento anual não apresentaram grande diferença em relação ao conjunto da América portuguesa. A grande quantidade de dados analisados até aqui não indica que o período de vigência do Diretório tenha tido efeitos “catastróficos" sobre a população indígena, aldeada ou não. Na verdade, os dados disponíveis mostraram viabilidade dessas povoações da Amazônia colonial.

A sobrevivência de uma população depende de seu tamanho e de sua composição em termos de idade e sexo. Uma população de poucas dúzias de indivíduos tem poucas chances de sobreviver como grupo, já que sua vulnerabilidade é muito grande diante de acasos ou eventos externos que distorçam muito a razão de sexo na população ou na distribuição por idade, comprometendo a capacidade reprodutiva do grupo, a divisão do trabalho, etc. Livi-Bacci inclina-se a aceitar a hipótese de uma "população mínima viável”, um nível abaixo do qual a probabilidade de sobrevivência do grupo declina a longo prazo. Esse mínimo depende de vários fatores, mas o autor indica um número de referência entre 100 e 500 indivíduos (LIVI-BACCI, 2016, p. 441-443). Na capitania do Pará, a média da população das oito vilas de brancos no mapa de 1776 era de 1.388 habitantes; nas 29 vilas de índios, a média era de 663 habitantes e, nos 22 lugares de índios, 201. Na capitania do Rio Negro, segundo dados do mesmo mapa, a população média das nove vilas era de 523 habitantes, e a dos lugares, de 209 habitantes. As povoações menores, como se sabe, tinham um número pouco significativo de escravos.

Os dados sugerem que essa dimensão das povoações não comprometia a proporção entre os sexos de maneira a inviabilizar a estabilidade demográfica. A razão de masculinidade no Pará em 1776 era de 103,2 homens por 100 mulheres entre os livres à exceção dos índios aldeados e de 89,5 entre os índios aldeados. Em 1785, essas razões eram exatamente as mesmas. Na capitania do Rio Negro, nesse mesmo ano, as razões eram de 95,6 para os livres à exceção dos índios aldeados e de 101 para os índios aldeados; em 1776, eram de 92,3 e 93,3, respectivamente. Nada disso sugere populações sob extrema pressão demográfica, “insustentáveis” ou "artificiais”.

\footnotetext{
$\overline{47}$ O número de escravos na capitania do Rio Negro era muito reduzido, como se sabe. 0 importante e abrangente trabalho de Tarcísio Botelho (2011, p. 11-12), valendo-se de fontes secundárias, acabou reproduzindo, no caso do Rio Negro, um erro de Clotilde Paiva et al. (1990, p. 32): estimou um número absolutamente improvável para a população escrava do Amazonas (capitania do Rio Negro) em 1808: 7.400 indivíduos (incompatível, aliás, com os números que ele mesmo apresenta para $1830-594$ escravos).
} 
Portanto, as informações qualitativas e quantitativas de que dispomos mostram que a população indígena das povoações coloniais (aldeada ou não) logrou elaborar formas de adaptação (ou resistência adaptativa - MONTEIRO, 2001) amiúde bem-sucedidas no sentido de preservar espaços de autonomia e de sobrevivência. A população livre como um todo parece ter conseguido se adaptar às condições ambientais e econômicas, criando uma sociedade capaz de reproduzir-se na região.

\section{Referências}

ALDEN, D. The population of Brazil in the late eighteenth century. The Hispanic American Historical Review, n. 43, p.173-205, maio 1963.

ALMEIDA, M. R. C. D. Os vassalos d'el Rey nos confins da Amazônia: a colonização da Amazônia Ocidental (1750-1798). Dissertação (Mestrado em História) - Universidade Federal Fluminense, Niterói, 1990.

AMAZONAS, L. Diccionario topographico, historico, descriptivo da Comarca do Alto-Amazonas. Recife: Typographia Commercial de Meira Henriques, 1852.

BARATA, F. J. R. Diário da viagem a colônia holandeza de Surinam, feita pelo porta-bandeira da sétima companhia do regimento da cidade do Pará, pelos sertões e rios d'este Estado, em diligencia do Real Serviço. Revista Trimestral do Instituto Histórico e Geográfico do Brasil, Rio de Janeiro, n. VIII, p. 1-53, 1846 [1797].

BEZERRA NETO, J. M. Escravidão negra no Grão-Pará. Belém: Paka-Tatu, 2014.

BIRABEN, J.-N. Epidemias na história da população. In: MARCÍLIO, M. L. População e sociedade: evolução das sociedades pré-industriais. Petrópolis: Vozes, 1984. p. 110-136.

BLUTEAU, R. Vocabulario portuguez \& latino. Lisboa: Officina de Pascoal da Sylva, 1716.

BOTELHO, T. R. Estimativas de população para o Brasil, séculos XVIII e XIX. In: V JORNADAS URUGUAIAS DE HISTÓRIA ECONÔMICA. Anais... Montevidéu: Universidad de la Republica, 2011.

BOXER, C. R. Relações raciais no império colonial português. Rio de Janeiro: Tempo Brasileiro, 1967.

. The golden age of Brazil: growing pains of a colonial society (1695-1750). 2. ed. Manchester: Carcanet, 1995.

CARRARA, Â. A. A população do Brasil, 1570-1700: uma revisão historiográfica. Revista Tempo, v. 20,p. 1-21, 2014.

CHAMBOULEYRON, R. Povoamento, ocupação e agricultura na Amazônia colonial (1640-1706). Belém: UFPA, Açaí, 2010.

CONSTITUIÇÕES Primeiras do Arcebispado da Bahia, feitas e ordenadas pelo Ilmo. e Rmo. Senhor D. Sebastião Monteiro da Vide. São Paulo: Typographia 2 de Dezembro, 1853 [1707].

CROSBY, A. Imperialismo ecológico: a expansão biológica da Europa: 900-1900. São Paulo: Companhia das Letras, 2011.

DANIEL, J. Tesouro descoberto no máximo rio Amazonas. Rio de Janeiro: Contraponto, v. 1, 2004 [1776].

DENEVAN, W. M. The native population of Amazonia in 1492 reconsidered. Revista de Indias, V. 63 , n. 227, p. $175-188,2003$.

FONSECA, A. A. D. Reformismo ilustrado e política colonial: negociações e resistência na Capitania do Rio Negro (1751-1798). Tese (Doutorado em História Social) - Programa de Pós- Graduação em História Social do Instituto de Filosofia e Ciências Socias da Universidade Federal do Rio de Janeiro (UFRJ), Rio de Janeiro, 2016. 
FURTADO, F. X. D. M. DIRECTORIO que se deve observar nas Povoaçoens dos Índios do Pará, e Maranhão em quanto Sua Magestade não mandar. Lisboa: Officina de Miguel Rodrigues, 1758.

HEMMING, J. Fronteira amazônica: a derrota dos índios brasileiros. São Paulo: Editora da Universidade de São Paulo, 2009 [1978].

HOLLINGHSWORTH, T. Uma conceituação de demografia história e as diferentes fontes utilizadas em seu estudo. In: MARCílIO, M. L. Demografia histórica. São Paulo: Pioneira, 1977. p. 23-39.

IMHOF, A. E. A mortalidade europeia do século XVIII ao XX: resultados e problemas. In: MARCíLIO, M. L. População e sociedade: evolução das sociedades pré-industriais. Petrópolis: Vozes, 1984. p. 247-265.

KELLY-NORMAND, A. Fontes primárias para a história de índios destribalizados na região amazônica. Boletim de Pesquisa da CEDEAM, Manaus, v. 5, n. 8, p. 92-119, jan./jul. 1986.

Family, church, and crown: a social and demographic history of the lower Xingu valley and the municipality of Gurupá, 1623-1889. Tese (PhD in History) - University of Florida, Gainesville, 1984.

LIVI-BACCI, M. Crises de mortalidade: definição, métodos de cálculo, análise das consequências. In: MARCÍLIO, M. L. População e sociedade: evolução das sociedades pré-industriais. Petrópolis: Vozes, 1984. p. 69-109.

The depopulation of upper Amazonia in colonial times. Revista de Índias, v. 76, n. 267, p. 419-448, 2016.

MADEIRA, A. B. As fontes demográficas de antigo regime nos Açores. Arquipélago - História, 2aㅗ série, v. 3, p. 139-176, 1999.

MARCÍLIO, M. L. A cidade de São Paulo: povoamento e população 1750-1850. São Paulo: Pioneira, 1973.

. La población del Brasil colonial. In: BETHELL, L. História de América Latina - 4. América Latina colonial: población, sociedad y cultura. Barcelona: Crítica, 1990. p. 39-59. Edusp, 2000.

Crescimento demográfico e evolução agrária paulista: 1700-1836. São Paulo: Hucitec,

MATOS, P. T. D. Population censuses in the portuguese empire, 1750-1820: research notes. Romanian Journal of Population Studies, v. II, n. 1, p. 5-26, Jan./Jun. 2013.

MATOS, P. T. D.; SOUZA, P. S. E. A estatística da população na América portuguesa, 1750-1820. Memorias. Revista Digital de Historia y Arqueología desde el Caribe, Barranquilla, n. 25, p. 72-103, enero-abril 2015.

MATTOS, Y. D. Regimento das Missões do Estado do Maranhão e Grão-Pará, de 21 de dezembro de 1686. 7 Mares, n. 1, p. 112-122, outubro 2012.

MEIRA, M. Livro das canoas: documentos para a história indígena da Amazônia. São Paulo: USP/Fapesp, 1994.

MONTEIRO, J. M. Tupis, tapuias e historiadores: estudos de história indígena e do indigenismo. Tese Apresentada para o Concurso de Livre Docência. Campinas: IFCH Unicamp, 2001.

MOREIRA NETO, C. D. A. Os principais grupos missionários que atuaram na Amazônia brasileira entre 1607 e 1759. In: HOORNAERT, E. (Org.). História da igreja na Amazônia. Petrópolis: Vozes, 1992. p. 63-120.

NORONHA, J. M. D. Roteiro da viagem da Cidade do Pará até as últimas colônias do sertão da Província. Belém: Typographia de Santos e Irmãos, 1862 [1768]. 
PAIVA, C. A.; CARVALHO, J. A. M. D.; LEITE, V. D. M. Demografia. In: IBGE. Estatísticas Históricas do Brasil. 2. ed. Rio de Janeiro: IBGE, 1990. p. 19-52.

PAIVA, E. F. Dar nome ao novo: uma histórica lexical da Ibero-América entre os séculos XVI e XVIII (as dinâmicas de mestiçagens e o mundo do trabalho). Belo Horizonte: Autêntica, 2015.

PAIVA, E. F. Escravo e mestiço: do que estamos efetivamente falando? In: PAIVA, E. F.; FERNÁNDEZ CHAVES, M. F.; PÉREZ GARCÍA, R. M. De que estamos falando? Antigos conceitos e modernos anacronismos - escravidão e mestiçagens. Rio de Janeiro: Garamond, 2016. p. 57-81.

PINHEIRO, G. S. P. Documentos inéditos de Lourenço Pereira da Costa, Provedor da Fazenda Real e Intendente do Comércio, Agricultura e Manufatura da Capitania de São José do Rio Negro. Boletim de Pesquisa da CEDEAM, Manaus, v. 2, n. 3, p. 58-81, jul./dez. 1983.

PORRO, A. O povo das águas: ensaios de etno-história amazônica. Petrópolis: Vozes, 1995.

RAMINELLI, R. Depopulação na Amazônia colonial. In: XI ENCONTRO NACIONAL DE ESTUDOS POPULACIONAIS. Anais... Caxambu: Abep, 1998. p. 1359-1376.

REIS, A. C. F. História do Amazonas. 3. ed. Belo Horizonte: Itatiaia, 1989.

SAMPAIO, F. X. R. D. Diario da viagem que em visita, e correição das povoações da Capitania de S. Joze do Rio Negro fez o ouvidor, e intendente geral da mesma. Lisboa: Tipographia da Academia, 1825 [1775].

SAMPAIO, P. M. M. Espelhos partidos: etnia, legislação e desigualdade na colônia - sertões do Grão-Pará (1755-1823). Manaus: Editora da Universidade Federal do Amazonas, 2011.

SANCHEZ-ALBORNOZ. La población de la América colonial española. In: BETHELL, L. Historia de América Latina -4. América Latina colonial: población, sociedad y cultura. Barcelona: Editorial Crítica, 1990. p. 14-38.

SCHWARTZ, S. B. Segredos internos: engenhos e escravos na sociedade colonial (1550-1835). São Paulo: Companhia das Letras, 1988.

SENELLART, M. As artes de governar: do regimen medieval ao conceito de governo 2006. São Paulo: Editora 34, 2006.

SOUSA, C. A. F. D. Noticias geographicas da capitania do Rio Negro no Grande Rio Amazonas. Revista Trimestral do Instituto Histórico e Geographico Brasileiro, Rio de Janeiro, v. X, $4^{\circ}$ trimestre, p. 411-503, 1848.

VIDAL, L. Mazagão, cidade que atravessou o Atlântico: do Marrocos à Amazônia (1769-1783). São Paulo: Martins, 2008.

VIEIRA JÚNIOR, A. O.; MARTINS, R. S. Epidemia de sarampo e trabalho escravo no Grão-Pará (1748-1778). Revista Brasileira de Estudos de População, Rio de Janeiro, v. 32, n. 2, p. 293-311, maio/ago. 2015.

VIRGOLINO-HENRY, A.; FIGUEIREDO, A. N. A presença africana na Amazônia colonial: uma notícia histórica. Belém: Arquivo Público do Pará, 1990.

\section{Sobre o autor}

André Augusto da Fonseca é doutor em História Social pela Universidade Federal do Rio de Janeiro (UFRJ) e mestre em Educação pela Universidade Federal do Rio Grande do Sul (UFRGS). Professor no curso de Licenciatura em História da Universidade Estadual de Roraima (UERR). Foi bolsista Capes durante parte da pesquisa de doutoramento. 


\section{Endereço para correspondência}

Universidade Estadual de Roraima - Coordenação do Curso de Licenciatura em História Rua 7 de Setembro, 231, Canarinho

69306-530 - Boa Vista-RR, Brasil

\section{Abstract}

Population Tables in Grao-Para captaincies: consolidation of a colonial population in the final half of the XVIIIth century

As of the mid-eighteenth century, in the context of the so-called Pombaline Reforms, Indian Freedom Laws incorporated a large region in northern Portuguese America into civilian administration, transforming more than sixty missionary settlements into Portuguese villages and sites with predominantly indigenous population. This paper seeks to research into the demographic evolution of "aldeado" (subject to compulsory labour) indians and the free non"aldeado" population under this new regime. For some historians, the population of Indian villages under the Directorio (1757-1798) was artificially maintained by the constant influx of new contingents of native peoples through descimentos. However, the analysis of population tables produced since 1773 shows a slow but consistent growth of all population groups in the captaincies of the State of Grão-Pará, even suffering frequent epidemics and harm from compulsory work to which by the majority of the indigenous population was subject.

Keywords: Amazon - Colonial History. Indigenous people. Indigenous policies.

\section{Resumen}

Los mapas de población en el Estado de Grão-Pará: consolidación de una población colonial en la segunda mitad del siglo XVIII

Desde mediados del siglo XVIII, en el contexto de las denominadas reformas pombalinas, las Leyes de Libertad de los Indios incorporaran una inmensa región en el norte de la América portuguesa a la administración civil y transformaron más de sesenta reducciones misioneras en municípios portugueses de población predominantemente indígena. Esta investigación se propone investigar la evolución demográfica de los indios «aldeados» y de la población libre no «aldeada» bajo el nuevo régimen. Para una parte de la historiografía, la población de las villas y lugares indígenas se mantuvo artificialmente, en el marco del Directorio (1757-1798), por el suministro constante de nuevos contingentes de pueblos nativos por medio de los descensos. Sin embargo, el análisis de los mapas de población compilados desde 1773 muestra un crecimiento lento pero consistente de todos los grupos de población de las capitanías del estado de Grão-Pará, a pesar de las epidemias frecuentes y de los daños provocados por el trabajo obligatorio que sujetaba a la mayoría de la población indígena.

Palabras clave: Amazonia. História colonial. Políticas indigenistas. Pueblos indígenas. Políticas indígenas. 